\title{
MEDIATING EFFECT OF PSYCHOLOGICAL CAPITAL ON THE RELATIONSHIP BETWEEN SPIRITUAL LEADERSHIP AND PERFORMANCE
}

\section{Elif Baykal, Cemal Zehir}

\section{Introduction}

The challenging work environment of the $21^{\text {st }}$ century has resulted in a great deal of global, societal and organizational change (Fry, 2003). We are experiencing a global crisis of confidence that has spread among many people and organizations (Parameshwar, 2005). Corporate fraud (Schroth \& Elliot, 2002), negativity stemming from the downsizing of companies, anxieties resulting from emerging technologies (Giacalone \& Jurkiewicz, 2003), and the financial crisis have affected the way employers see their organizations and leaders. Congruent with that reality, organizations have started to give more importance to positivity and developing strong characteristics of employees, rather than focusing on negativity and weaknesses (Avey, Luthans, \& Jensen, 2009). Similarly, academics and organizational behaviour experts started to focus on positivity and positive sides of organizational life. This change in mentality brought about the need for a more holistic leadership style that can integrate minds and souls of people: namely, spiritual leadership.

In relation to all of these factors, major global firms have embraced workplace spirituality in order to benefit from integrating the hearts and minds of their employees (Fry, 2003; Mitroff \& Denton, 1999; O'Reilly \& Pfeffer, 2000; Weinberg \& Locander, 2014). This new way of thinking has brought about a new kind of leadership which is spiritual leadership, which integrates the four main components of human existence: body, mind, heart, and spirit (Moxley, 2000). Without doubt, employees have both spiritual and physical needs and these needs come to work with them. In fact, inner life integrity and wholeness of soul necessitate having an opportunity to live one's inner life at work (Duchon \& Plowman, 2005). Thus, issues and trends relating to spirituality have become emerging factors for human growth and wellbeing.

\section{Theoretical Framework}

Spirituality is considered to be a psychological pattern that embraces a meaningful life, wholeness, and interconnectedness with other people and entities (Zinnbauer, Pargament, \& Scott, 1999). In the extant literature, spirituality has been explained as the search for a vision that encompasses service to others, humility, charity and veracity. Although they are often confused, spirituality is not exactly the same as religion. According to Zinnbauer, Pargament, and Scott (1999), religion is often associated with institutional religion, whereas spirituality is often associated with inner feelings of people related to their proximity to God and their interconnectedness with other people and entities.

The term 'workplace spirituality' has evolved from the above-mentioned spirituality concept. It is a multidimensional concept, involving a special relationship with one's own self and values (Fairholm, 1996), meaning and purpose obtained through a transcendental practice of work (Giacalone \& Jurkiewicz, 2003), and a need for connectedness (Giacalone \& Jurkiewicz, 2003; Pfeffer \& Salancik, 2003). A leader can develop workplace spirituality by explaining the necessary ways to live it and by living it himself (Konz \& Ryan, 1999). Employees under spiritual leaders are more courageous, more moral, and more loyal to their organizations (Fry, 2003).

\subsection{Spiritual Leadership}

Spiritual leadership is very much related to morality and supports kindness, righteousness, team work, congruence, completeness and correspondence (Zellers \& Perrewe, 2003). As mentioned before, spiritual leadership literature 
follows the emerging paradigm of spirituality at work, due to the shift toward a concern for wholeness and spiritual values (Weinberg \& Locander, 2014).

The spirituality at work literature is the starting point for spiritual leadership theory. Kouzes and Posner (1993) started the process and indicated the top four characteristics of leaders as their being honest, forward-looking, inspirational, and competent. Next, Fairholm's (1996) work extended spiritual leadership. Mitroff and Denton (1999) contributed to the spirituality at work field with their publication entitled A Spiritual Audit of Corporate America. Furthermore, Ashmos and Duchon (2000) made a conceptualization and designed a measure of spirituality at work. Finally, Fry's (2003) Toward a Theory of Spiritual Leadership article presented a developed model for spiritual leadership. His theory based on an intrinsic motivation model (Chen, Yang, \& Li, 2011) that incorporated vision, hope/faith, and altruistic love and, in addition to these, theories of workplace spirituality and spiritual well-being.

According to Maddock and Fulton (1998), workplace spirituality is composed of two important categories: calling and the need for connectedness. These two categories are interlocked and universal (Fry, 2003). According to Fry (2003), spiritual leadership is necessary for intrinsically motivating one's self and others toward spiritual survival through these two categories; i.e., calling and membership. In this sense, calling entails creating a vision so that employees experience a sense of relatedness and engagement which entails a relatedness in their work. Membership ensures a culture based on altruistic love wherein leaders and followers genuinely care for and appreciate others.

Spiritual leadership draws from an inner life nourished by spiritual practice that develops values, attitudes, and behaviours necessary to intrinsically motivate one's self and others so that people build a sense of spiritual well-being (Fry \& Cohen, 2009). Calling and membership are two important responses of followers to spiritual leadership. In the spiritual leadership context, calling means a need coming from one's inner world or from a higher power that sometimes takes the form of service to an ideal or service to God (Reave, 2005). The second response is membership. With the help of membership, followers experience meaning in their lives and feel capable of making a difference, being understood, and being appreciated by their leaders (Fry et al., 2005). According to Paloutzian, Emmons and Keortge (2003), seeing work as a calling rather than a mundane job contributes to giving importance and meaning to it. Employees viewing their jobs as a vocation rther than as a tool for earning money behave and feel in a quite meaningful and satisfied (Fry \& Slocum, 2008).

On the one hand, Fry's (2003) description of membership involves establishing a culture based on altruistic love, whereby leaders and followers have genuine care, concern, and appreciation for both their own selves and for the people around them. Feelings of membership contribute to the perception of being understood and appreciated in this affectionate culture. Fry's (2003) cause-andeffect model of spiritual leadership involves three spiritual leadership dimensions that are mediated by two follower characteristics that contribute to superior organizational outcomes. Leadership components are: (1) vision that is a passion for an appealing future and creates high level standards for perfection; (2) hope or faith that is the source of the belief that the organization has the capital to thrive and its goals will probably be successful (Fry, 2003); and (3) altruistic love which means that wholeness, integration, congruence, and wellbeing come about through care, concern, and appreciation.

On the other hand, the two follower characteristics are: (1) meaning/calling - the experience of transcendence or how one makes a difference through service to others and, in doing so, derives meaning and purpose in life; and (2) membership - the feeling of being understood and appreciated in a specific group (Chen, Yang, \& Li, 2011).

In spiritual leadership, the compelling vision produces a sense of calling that part of spiritual survival that gives one a sense of making a difference and, thus, one's life has meaning (Fry et al., 2005). Moreover, sub-dimensions of spiritual leadership such as vision, hope or faith add belief, trust and motivation to achieve the vision (Fry et al., 2005). Hope/faith keeps followers agile and optimistic and contributes to intrinsic motivation (Fry, 2003).

One of the above-mentioned dimensions of spiritual leadership -altruistic love- is given by the organization and is received in turn by 
followers with the aim of providing a common vision that removes fears associated with worry, anger, jealousy, selfishness, failure, and guilt and contributes to a sense of membership which results in being understood and appreciated (Fry et al., 2005). This intrinsic motivation cycle results in an increase in one's sense of spiritual survival (e.g., calling and membership) and ultimately in positive organizational outcomes such as high levels of organizational commitment and productivity (Fairholm, 1998; Fry, 2003; Fry et al., 2005).

To sum up, Fry's (2003) theory also encompasses religious-based aspects based on value, care, and love; an ethics-based aspect that values responsibility and consideration and a value-based aspect that values meaning and positive interpersonal relationships (Chin \& $\mathrm{Li}$, 2011). According to Fairholm (1996; 1998), stemming from an inspiring vision and mission developed by spiritual leaders, under spiritual leadership a culture occurs where factors like trust, collaboration, mutual interest, commitment to team, and organizational effectiveness are developed.

\subsection{Positive Psychological Capital}

The term 'positive psychological capital' (PsyCap) is a product of the positive psychology movement which focuses on strengths rather than weaknesses and positivity rather than negativity of humankind (Luthans et al., 2004). It is a concept of positive organizational behavior - a branch of organizational behaviour that studies positive human behaviour and focuses on strengths and psychological capacities which have the capacity and feasibility of being measured, developed, and managed for a superior performance (Luthans, 2002, p. 59). Unlike positive traits, that are relatively stable over time, positive state-like capacities are not so stable and are open to change and development (Luthans, 2002; Luthans et al., 2007) and they can be grouped into four categories: confidence, hope, optimism, and resilience.

Self efficacy: According to Stajkovic and Luthans (1998) self efficacy is an individual's belief in his capabilities, resources and abilities in order to be successful in a specific area or in his job. This concept focuses on beliefs and convictions about one's own capabilities and the probability of being successful in relation to those positive convictions. Unlike personality traits which are quite fixed, self-efficacy is a state-like and dynamic capacity and can change over time as a result of learning. Studies have proven that the level of self efficacy affects the likelihood that a person will initiate a certain task and persist even in times of adversity (Bandura, 1997; Stajkovic \& Luthans, 1998).

Hope: According to Snyder et al. (1991), hope is a positive motivational state that encompasses (a) willpower - namely, goaloriented energy, and (b) pathways that are plans to meet goals (Luthans et al., 2004). The willpower dimension of hope is similar to efficacy expectancies and the pathway dimension is conceptually close to efficacy outcome expectancies (Luthans, 2002). When compared with optimism, it is noteworthy that optimism expectancies are formed through outside forces, while Snyder's (2000) hope is initiated and determined through the self.

Optimism: Optimism is perhaps more closely associated with overall positive psychology than the other constructs (Luthans et al., 2004). Optimism is an attributional style that explains positive events in terms of personal, permanent, and pervasive causes and negative events in terms of external, temporary, and situation-specific ones (Youssef \& Luthans, 2007) Optimism can be learned, validly and reliably measured, and has a recognized performance impact in work settings meeting the Positive organizational behavior criteria (Youssef \& Luthans, 2007).

Resilience: This is the capacity to 'bounce back' from adversity and to be astute and perseverant in times of uncertainty, conflict, failure, or even positive change, progress, and increased responsibility (Luthans, 2002). The main difference between self efficacy and resilience is that resilience is reactive rather than proactive (Luthans, 2002), being statelike and thus open to development. Resilience contributes to social skills, problem-solving skills, autonomy, self confidence and a sense of purposefulness (Bandura, 2000).

\section{Methodology}

As mentioned before, the challenging and changing work environment of the 21st century has given rise to a greater emphasis on positivity and development of strengths. This mentality change has brought about the need for a more holistic leadership style - namely, spiritual leadership - that can integrate minds 
and souls of people. In our study, we focused on this holistic leadership style and its relationship with performance and psychological capital. We wanted to see the relationship between spiritual leadership and individual performances of followers and we expected that perceived organizational support may have a mediator effect in this relationship.

\subsection{Research Questions and Hypotheses}

Spiritual leaders deliberately and willingly try to make positive change in their environment. They first prepare a trustworthy climate that contributes to the progress of their followers; then, they empower, motivate and train their followers and contribute to their development (Fairholm, 1996). Thus, they enhance the necessary atmosphere for optimistic and competent individuals. They ensure that their followers enhance their self efficacy and self motivation which make them feel safe in their jobs (Fry, 2003). Hence, despite risky situations, those leaders search for permanent solutions to people's problems (Fairholm, 1996) and they contribute to the establishment of resilient organizations that are efficient in developing employees, and prosperous because they seize opportunities and cultivate new talents (Lengnick-Hall, Beck, \& Lengnick-Hall, 2011).

In the extant literature, although there is a scarcity of studies focusing on the relationship between spiritual leadership and psychological capital, there are enough studies on the relationship between spirituality and sub-dimensions of psychological capital. For example, Lucette et al.'s (2016) study, involving 1696 people with chronic illnesses and depression, showed that spirituality is useful in combatting depression and other similar illnesses, owing to its contribution in building hope and inner peace. Another study conducted by Fehring et al. (1997) on 100 cancer patients investigated the relationship between spiritual well-being, spirituality/religiosity, hope, and depression and as a result of the study, strong correlations have been found between spirituality/religiosity and hope, and between spirituality/religiosity and positive well being (Fehring et al., 1997). Bonelli et al.'s (2012) meta-analysis, which encompassed the time period between 1962 and 2011, considered 444 studies and focused on the relationship between spirituality and depression, showed that patients with high levels of spirituality have been proven to be more resistant to depression in $67 \%$ of the studies. Furthermore, they seem to be more successful in overcoming depression and more resistant to other psychological illnesses. Similarly, Koenig et al. (2012) investigated 326 studies regarding spiritual well-being; in $79 \%$ of the studies, satisfaction with life, being happy, and having a high level of psychological well-being were shown to be positively related to religiosity and spirituality. In at least 40 studies, a meaningful relationship has been found between spirituality and hope and in 26 studies a meaningful relationship has been found between optimism and spirituality. Moreover, in 45 studies, a meaningful relationship has been found between having a purpose/having a sense of meaning and high levels of spirituality. Furthermore, 42 studies regarding self efficacy showed that there is a strong correlation between spirituality and self efficacy. Inspired by all those studies, we wanted to see the effects of spiritual leadership on positive psychological capital; we expected that in an organizational context spiritual leadership would contribute to extended levels of psychological capital for followers. Thus, our first hypothesis was as follows:

H1: Spiritual leadership is positively related to psychological capital.

Furthermore, we wanted to investigate the relationship between PsyCap and spiritual leadership. As mentioned before, PsyCap is a second order factor composed of four sub dimensions: hope, optimism, resiliency, and self efficacy (Luthans et al., 2007) that incorporates shared properties of the four mentioned factors. The synergic effect among them forms a sound basis for satisfying performance and motivation (Stajkovic, 2006). Thus, in the extant literature studies conducted on PsyCap have often accepted it as a second order factor and have not preferred to analyse sub-dimensions.

Up until now, the most frequently investigated topic regarding psychological capital is its relationship with performance and the common deduction that can be made from these studies is its positive effect on performance and extra role behaviour (Luthans, 2002; Avey et al., 2010; Luthans et al., 2007; Walumbwa et al., 2009). For example, in Luthans et al.'s (2005) study based on 422 Chinese workers, the relationship between 
psychological capital and performance was investigated and results showed that when both of the two relationships between performance and sub-dimensions of psychological capital and between performance and psychological capital as a high order concept are studied, the relationship in the latter situation has been found to be stronger. Similarly, Luthans, Avey, Clapp-Smith, and Li (2008) conducted a study at a Chinese copper mine with 456 workers and their study showed that psychological capital has a meaningful effect on employee performance. It was deduced that psychological capital is a good complementary factor for satisfactory human resources implementations.

In this manner, Luthans et al. (2008) conducted a research study with the aim of investigating the relationship between PsyCap, organizational climate, and performance. The results proved that PsyCap has a perfect mediator effect in the relationship between supportive organizational climate and work performance. Again, in the Chinese context, Luthans et al., (2007) investigated the effects of PsyCap's sub dimensions on performance seperately and their synergic effect as a whole. They saw that when PsyCap's sub-dimensions are considered as a whole, they are more effective in contributing to high levels of performance. Moreover, they found that hope as a sub-dimension was more powerful in explaining the relationship compared to other sub dimensions of PsyCap. Moreover, Gooty et al. (2009) conducted a research study with 253 members of a Midwestern University band, to see the relationship between transformational leadership perceptions, PsyCap, and performance. As a result of this study, it was deduced that there is a strong relationship between PsyCap and in-role performance and organizational citizenship behaviour (Gooty et al., 2009). Carmeli, Ben-Hador, Waldman and Rupp (2009) also investigated the same relationship and supported the previous findings. Later, in Avey, Reichard, Luthans, and Mhatre's (2011) meta-analysis on PsyCap and work outcomes, 51 studies were examined (a total sample of 12,567). Strong relationships between PsyCap and desired work outcomes (job satisfaction, organizational commitment, psychological well-being) and desired employee behaviour (organizational citizenship behaviour, extra role performance, high level in role performance) were found and negative relationships between PsyCap and organizational cynicism, job stress, and anxiety were proven. Furthermore, Walumbwa, Peterson, Avolio, and Hartnell's (2010) study conducted in South America on 79 high level police leaders and 264 police officers confirmed that there is a meaningful relationship between leaders' PsyCap and followers' performance. Followers' PsyCap acts as a mediator in this relationship. Moreover, it has been shown that when service climate is more positive, a follower's own PsyCap is more effective in higher levels of performance.

From these example studies, we can claim that individuals with high levels of psychological capacities are prone to having higher levels of performance due to the satisfactory levels of self efficacy, higher levels of optimism, and hope in attaining long-term goals. People with high levels of PsyCap are successful in solving problems, due to the fact that they have the ability to put forward multidimensional solutions and because they have the necessary hope and optimism reservoir for combatting problems and adversity and overcoming burdens of stressful events. All these advantageous properties ensure high levels of performance and allow them to thrive more easily, compared with mediocre people. We expect that high levels of followers' PsyCap will result in higher levels of performance. Thus we hypothesized:

H2: Psychological capital is positively related to individual performance.

Moreover, spiritual leadership creates a work environment in which individuals love each other and become committed to their work, resulting in higher organizational faithfulness and productivity (Fry, 2003). In spiritually-led organizations, every member feels empowered and responsible for the reputation of the company (Fry \& Slocum, 2008). Spiritual leaders are long-term oriented, challenging leaders, obsessed with excellence, and their followers are also committed to meeting performance levels required to reach the preferred and envisioned future (Fry \& Slocum, 2008).

The meta-analysis carried out by Reave (2005) extracted the spiritual qualities and practices that have been studied as measures of leadership success. It is commonly thought that there is a conflict between values and practices emphasized in spiritual teachings and those 
required for a successful leadership (Reave, 2005). But, Reave's (2005) meta-analysis showed that there is considerable agreement about the elements of success in both fields. Reave (2005) reviewed over 150 studies and concluded that spiritual values and practices are connected to leadership effectiveness.

Effects of spiritual leadership on performance are closely linked to a few major factors. Firstly, spiritual leaders are good at contributing to the cognitive capabilities of their followers by increasing their level of awareness and intuitive profundity (Vaughan, 1989). Secondly, they serve to their followers a charming, meaningful, and alluring vision that entices them to perform at their best (Hawley, 1993). Thirdly, spiritually-led work goals give passion and ardour to followers in their service of others (Hawley, 1993). Moreover, the demands of spiritual leadership for spiritual vision contribute to the establishment of a strong tie between employees and the organization, and enhance teamwork and organizational commitment (Neck \& Milliman, 1994).

The extant literature on spiritual leadership gives enough evidence that there is a meaningful relationship between spiritual leadership and performance. In fact, employees that find answers to their search for meaning at work experience higher levels of job satisfaction (Wrzesniewski, 2003); thus, due to the positive relationship between job satisfaction and performance, they produce better and more qualified work outcomes (Duchon \& Plowman, 2005; Salehzadeh et al., 2016). Later, Chen and Yang's (2012) study showed that spiritual leadership behaviour has a positive effect on giving meaning to work and eliciting organizational commitment of individuals and proved that Fry's (2003) theory is also binding in the Chinese context (Chen \& Yang, 2012). On the one hand, Salehzadeh et al.'s (2015) study on 46 hotels and 207 employees in Iran focused on spiritual leadership's effects on organizational performance. In this study, a meaningful relationship was found between spiritual leadership and two follower behaviours - meaning and calling dimensions - and an important relationship between these dimensions and performance was found. Lastly, in Fry and Slocum's (2008) study, in a spiritually-led organization, Interstate Batteries, an investigation was conducted using 347 employees and 43 distributors. In this study, the relationship between sub-dimensions of spiritual leadership - hope/faith, vision, altruism, and the two follower behaviours, meaning and calling - and organizational outputs such as organizational commitment and productivity have been investigated. Results showed that their spiritual leadership is effective in increasing sales, distributor productivity, and enhancing the two follower behaviours (meaning and calling).

Thus, inspired by the extant literature and previous studies, we expected that by giving meaning to their work, by setting optimistic values, and by instilling hope and altruism in followers, spiritual leadership would contribute to higher levels of performance. Thus, we hypothesized that:

H3: Spiritual leadership is positively related to employee performance.

Although in the extant literature studies have not directly investigated the relationship between spiritual leadership, performance, and PsyCap, there are some studies which prove that some of the sub-dimensions of PsyCap act as a mediator in the relationship between spiritual leadership and performance. Under those situations in which organizations promote hope and happiness, doubtless employees become more capable in dealing with stressors in the work environment (Edwards \& Cooper, 1988; Simmons \& Nelson, 2001), thus contributing to organizational performance. In organizations led by high levels of spirituality, it has been shown that employees are more flexible and resilient, and they are less resistant to change (Jurkiewicz \& Giacalone, 2004), which is why their performance is more satisfactory in the face of demanding goals and in times of adversity. Nonetheless, the hopeful environment resulting from spiritual leadership ensures resilience on the part of followers, contributes to an optimistic point of view regarding vision and goals of the organization, and makes followers more resilient by making them more successful in showing high levels of performance (MacArthur, 1998). For example, in the study conducted by Chen, Yang and $\mathrm{Li}$ (2011), in the Taiwanian and Chinese context on 20 companies and 502 employees, effects of spiritual leadership dimensions on work outputs and self career management were investigated. As a result, it has been proven that spiritual leadership has a positive effect on productivity 
and self career management. Results also show that self confidence and self efficacy act as mediators between spiritual leadership and organizational outcomes, such as productivity and superior performance. In the light of extant literature and previous research studies, we expected that PsyCap would probably act as a mediator between spiritual leadership and follower performance. Thus, we hypothesized that:

H4: PsyCap acts as a mediator in the relationship between spiritual leadership and performance.

\subsection{Research and Methods}

Face-to-face survey method and online survey method were used to collect data for the study. The constructs in our study were developed using measurement scales adopted from prior studies. Survey items were responded to on five-point Likert scales, with anchors ranging from strongly disagree (1) to strongly agree (5). Some of the items were negatively worded. After reversing these, as an independent variable, employee performance was measured by a six item measure created by combining Fuentes-Fuentes, Albacete-Sáez, and Lloréns-Montes's (2004) and Rahman and Bullock (2005)'s employee performance measures that tries to understand employees' own perceptions regarding their qualitative performance. A sample item included 'My abseenteism level is always low.' And we also borrowed four items measuring in role performance from Welbourne et al.'s (1998) role based performance measure. A sample item included 'My performance is always satisfying.' Psychological capital was measured by using Luthan's et al. (2007) 24-item PsyCap scale which is composed of four sub-dimensions: self efficacy, hope, optimism, resilience. This scale aims to measure employees' personal perceptions about their own psychological capacities which make them feel more efficant, hopeful, optimistic, and resilient. In this scale self efficacy dimension explains employee's conviction or confidence about his or her abilities to mobilize the motivation, cognitive resources or courses of action needed to successfully execute a specific task within a given context. A sample item includes 'I feel confident that I can accomplish my work goals. On the other hand, hope dimension explains individual's positive motivational state that is based on an interactively derived sense of successful (a) agency (goal directed energy) and (b) pathways (planning to meet goals). A sample item includes 'Now, I feel that I am energetic to accomplish the work goal. And optimism dimension explains positive framework regarding events, which includes positive emotions and motivation. A sample item includes 'I believe that success in the current work will occur in the future. And resilience dimension explains individual's positive coping and adaptation in the face of significant risk or adversity. A sample item includes' I usually manage difficulties one way or another at work. Lastly, spiritual leadership, which is the independent variable of our model, was measured using three leadership dimensions from Fry's (2003) spiritual leadership scale - vision, hope/faith and altruism - with 17 items. This scale measures employees' perceptions about their leaders' leadership style and tries to find out whether there are spiritual leadership qualities and behaviours in their organization or not. Vision dimension describes the organization's journey and why people are taking it. A sample item includes 'My organization's vision is clear and compelling to me.' Hope/faith dimension tries to find out the explaination for the assurance of things hoped for, explains the conviction that the organization's vision/purpose/mission will be fulfilled. A sample item includes 'I persevere and exert extra effort to help my organization succeed because I have faith in what it stands for. And altruistic love dimension explains the effects of spiritual leadership behaviour in creating a sense of wholeness, harmony, and well-being produced through care, concern, and appreciation for both self and others. A sample item includes 'My organization really cares about its people.

We used a convenience sampling method to collect our data. We gave 345 of our surveys to people working in İstanbul using the face-to-face survey method. However, the rest of the surveys were disseminated via an Internet survey program. We preferred to reach applicants from outside of İstanbul via the Internet. We distributed our surveys between August 2015 and April 2016.

\subsection{Sample Characteristics}

When collecting data, we focused on campanies from banking, finance, and production sectors located in İstanbul, with 100 branches all over 
Turkey, and which employed more than 1,000 employees. We proposed that investigating effects of leadership in corporate firms would be more meaningful due to the effects of distinct formal hierarchial relationships. In Turkey, İstanbul is the main business center and nearly all corporate firms are located in İstanbul; that is why we mainly focused on firms in İstanbul. And we assumed that white collar workers know more details about their organization's vision, mission, performance outputs, and leadership styles, and they have more chances of understanding leadership styles in their organization because they spend more time with their leaders. By putting a limit on the applicants' departments, we also tried to make a more homogenous sample regarding their roles.

Our sample data consists of 736 whitecollar workers from 167 large-scale firms from finance and production sectors listed in ISO 500. ISO 500 is a list of the first 500 firms with highest revenues in Turkey and these firms are choosen by the İstanbul Chamber of Commerce every year. All of the 167 firms in our sample data have more than 1,000 employees and more than 100 branches all over Turkey; 167 of 285 firms which conformed with our criteria agreed to take part in the study and participants of our study all work in service departments. Thus, they truly reflect our target population. Our sample is mostly composed of office workers; $66 \%$ are female, $93.5 \%$ are university graduates, and $69 \%$ work in service sector.
As seen in Tab. 1, 91\% of the participants are in managerial positions. Based on the departments and sectors of applicants and the scale of their companies, we can conclude that the research sample could be generalized to the whole population.

During the data collection process, we tried to get in touch with 285 firms which conformed to our criteria; we first sent emails to all those large-scale firms in the banking, finance, and production sectors which were selected from the ISO 500 list of 2016, asking if they would like to contribute to our research. One hundred and sixty-seven of these agreed to contribute to our study and we sent about 30 surveys to each of those companies. We waited for four weeks for each applicant's answer and we sent a letter of reminder for unreturned surveys. We had a response rate of $16 \%$. However, some of these were discarded due to excessive missing data, resulting in 736 useable questionnaires.

\subsection{Validity and Reliability of the Questionnaire}

Exploratory factor analysis (EFA) and confirmatory factor analysis (CFA) were conducted to see if the observed variables theoretically loaded together and to evaluate construct, convergent, and discriminant validity and reliability values. Afterwards, the research model and related hypotheses were investigated using the Structural Equation Modelling technique.

\section{Tab. 1: Factor loadings (Part 1)}

\begin{tabular}{|c|c|c|c|c|c|c|}
\hline \multirow{2}{*}{ Construct } & \multirow{2}{*}{ Items } & \multicolumn{4}{|c|}{ Factor Loading } & \multirow{3}{*}{\begin{tabular}{|c|} 
Scale Reliability \\
Cronbach $\alpha ; 0.921$
\end{tabular}} \\
\hline & & \multirow{2}{*}{$\frac{\text { EFA }}{0.687}$} & \multirow{2}{*}{$\begin{array}{c}\text { 1st ord CFA } \\
0.738\end{array}$} & \multicolumn{2}{|c|}{ 2nd order CFA } & \\
\hline \multirow{5}{*}{ Vision } & 1 & & & 0.739 & 0.937 & \\
\hline & 2 & 0.835 & 0.838 & 0.838 & & SCR; 0.925 \\
\hline & 3 & 0.867 & 0.861 & 0.862 & & AVE; 0.713 \\
\hline & 4 & 0.734 & 0.910 & 0.910 & & \\
\hline & 5 & 0.674 & 0.865 & 0.864 & & \\
\hline \multirow{5}{*}{ Hope/Faith } & 1 & 0.635 & 0.888 & 0.889 & 0.893 & Cronbach $\alpha ; 0.932$ \\
\hline & 2 & 0.841 & 0.896 & 0.896 & & SCR; 0.933 \\
\hline & 3 & 0.882 & 0.853 & 0.854 & & AVE; 0.735 \\
\hline & 4 & 0.870 & 0.790 & 0.789 & & \\
\hline & 5 & 0.820 & 0.855 & 0.855 & & \\
\hline
\end{tabular}




\section{Ekonomika a management}

\section{Tab. 1: Factor loadings (Part 2)}

\begin{tabular}{|c|c|c|c|c|c|c|}
\hline \multirow{2}{*}{ Construct } & \multirow{2}{*}{ Items } & \multicolumn{4}{|c|}{ Factor Loading } & \multirow{2}{*}{ Scale Reliability } \\
\hline & & \multirow{2}{*}{$\begin{array}{c}\text { EFA } \\
0.750\end{array}$} & \multirow{2}{*}{$\begin{array}{c}\text { 1st ord CFA } \\
0.849\end{array}$} & \multicolumn{2}{|c|}{ 2nd order CFA } & \\
\hline \multirow{6}{*}{$\begin{array}{l}\text { Altruistic } \\
\text { Love }\end{array}$} & 1 & & & 0.852 & 0.854 & Cronbach $\alpha ; 0.919$ \\
\hline & 2 & 0.837 & 0.841 & 0.842 & & SCR; 0.924 \\
\hline & 3 & 0.890 & 0.846 & 0.843 & & AVE; 0.708 \\
\hline & 4 & 0.915 & 0.858 & 0.858 & & \\
\hline & 5 & 0.736 & \multicolumn{3}{|c|}{ dropped } & \\
\hline & 7 & 0.864 & 0.811 & 0.809 & & \\
\hline \multirow{3}{*}{ Optimism } & 4 & 0.817 & 0.714 & 0.742 & 0.638 & Cronbach $\alpha ; 0.713$ \\
\hline & 5 & 0.602 & 0.907 & 0.796 & & SCR; 0.785 \\
\hline & 6 & 0.858 & 0.583 & 0.560 & & AVE; 0.557 \\
\hline \multirow{5}{*}{ Self Efficacy } & 1 & 0.718 & 0.768 & 0.769 & 0.841 & Cronbach $\alpha ; 0.900$ \\
\hline & 2 & 0.920 & 0.861 & 0.863 & & SCR; 0.903 \\
\hline & 3 & 0.945 & 0.854 & 0.854 & & AVE; 0.651 \\
\hline & 4 & 0.742 & 0.822 & 0.819 & & \\
\hline & 6 & 0.687 & 0.722 & 0.722 & & \\
\hline \multirow{3}{*}{ Resilience } & 2 & 0.521 & 0.798 & 0.790 & 0.877 & Cronbach $\alpha ; 0.826$ \\
\hline & 5 & 0.785 & 0.797 & 0.799 & & SCR; 0.843 \\
\hline & 6 & 0.767 & 0.807 & 0.811 & & AVE; 0.641 \\
\hline \multirow{5}{*}{ Hope } & 2 & 0.694 & 0.739 & 0.733 & 0.885 & Cronbach $\alpha ; 0.877$ \\
\hline & 3 & 0.717 & 0.811 & 0.811 & & SCR; 0.888 \\
\hline & 4 & 0.868 & 0.755 & 0.752 & & AVE; 0.615 \\
\hline & 5 & 0.826 & 0.861 & 0.864 & & \\
\hline & 6 & 0.724 & 0.749 & 0.753 & & \\
\hline \multirow{7}{*}{$\begin{array}{l}\text { Employee } \\
\text { Performance }\end{array}$} & 3 & 0.788 & 0.730 & 0.729 & & Cronbach $\alpha ; 0.906$ \\
\hline & 4 & 0.715 & 0.744 & 0.744 & & SCR; 0.904 \\
\hline & 5 & 0.788 & 0.793 & 0.794 & & AVE; 0.572 \\
\hline & 6 & 0.681 & 0.777 & 0.777 & & \\
\hline & 8 & 0.764 & 0.759 & 0.759 & & \\
\hline & 9 & 0.794 & 0.750 & 0.750 & & \\
\hline & 10 & 0.856 & 0.741 & 0.741 & & \\
\hline
\end{tabular}

(i) Principal Component Analysis with Promax Rotation

(ii) $\mathrm{KMO}=0.963$, Bartlett Test; $p<0.001$

(iii) Total Variance Explained (\%); 71.915

(iv) All CFA Paths are statistically significant at $p<0.001$

\begin{tabular}{l|l}
\hline 1st Order CFA & $X 2 / d f=2.059, \mathrm{GFI}=0.912, \mathrm{TLI}=0.963, \mathrm{CFI}=0.967, \mathrm{PNFI}=0.834, \mathrm{RMSEA}=0.039$ \\
\hline 2nd Order CFA & $\mathrm{X} 2 / \mathrm{df}=2.234, \mathrm{GFI}=0.901, \mathrm{TLI}=0.957, \mathrm{CFI}=0.960, \mathrm{PNFI}=0.851, \mathrm{RMSEA}=0.042$
\end{tabular}


Tab. 2: Correlation matrix

\begin{tabular}{l|c|c|c|c|c|c|c|c}
\multicolumn{1}{c|}{ Construct } & $\mathbf{1}$ & $\mathbf{2}$ & $\mathbf{3}$ & $\mathbf{4}$ & $\mathbf{5}$ & $\mathbf{6}$ & $\mathbf{7}$ & $\mathbf{8}$ \\
\hline Optimism (Psy Cap) & 0.747 & & & & & & & \\
\hline Altruistic Love (SL) & 0.557 & 0.841 & & & & & & \\
\hline Employee Performance & 0.457 & 0.439 & 0.757 & & & & & \\
\hline Self Efficacy (PsyCap) & 0.455 & 0.386 & 0.720 & 0.807 & & & & \\
\hline Hope / Faith (SL) & 0.459 & 0.753 & 0.479 & 0.431 & 0.857 & & & \\
\hline Vision (SL) & 0.500 & 0.806 & 0.475 & 0.409 & 0.838 & 0.844 & & \\
\hline Hope (Psy Cap) & 0.575 & 0.500 & 0.732 & 0.717 & 0.531 & 0.497 & 0.784 & \\
\hline Resilience (Psy Cap) & 0.447 & 0.345 & 0.738 & 0.786 & 0.401 & 0.373 & 0.778 & 0.801 \\
\hline
\end{tabular}

Source: own

Note: All correlations are statistically significant at $p<0.001$. Squared AVE values are represented in diagonals for Discriminant Validity

Using principal component analysis with promax rotation, an EFA was performed to see if the observed variables loaded together as expected and were adequately correlated. In order to test the congruence of the data set, we performed a factor analysis using the Kaiser-Meyer-Olkin (KMO) sample sufficiency test and Bartlett's test for equality of variances. As a result of the analysis, KMO was found to be 0.963 which is above the desired level of 0.50 and Bartlett's test was found to be at 0.001 level of significance. Moreover, in antiimage correlation, matrix diagonal values were examined and proven to be above the desired level of 0.5 .

Thus, it could be deduced that the sample data was appropriate for factor analysis. In exploratory factor analysis, the threshold for factor loadings were designated as 0.5 (Hair et al., 2010). In measuring the internal validity of factors, Cronbach's alpha values were computed; each Cronbach's alpha value was above 0.7. Thus, it was proven that there was internal validity between those factors and inner validity of all factors was proven.

In order to validate the EFA results and analyse validity and reliability of measures, Maximum Likelihood method confirmatory factor analyses were applied. In the study, standardized residual covariance values were analysed and an item was eliminated to improve the model fit to the data in CFA. Moreover, modification indexes were investigated and error values that had high modification values were covariated. In the end, fit indexes were found to be $\mathrm{X} 2 / \mathrm{df}=2.059, \mathrm{GFI}=0.912$, $\mathrm{TLI}=0.963, \mathrm{CFI}=0.967, \mathrm{PNFI}=0.834$, RMSEA $=0.039$. Because of the fact that in this study holistic effects of all sub-divisions of spiritual leadership and the holistic effect of PsyCap's sub-dimensions as a second-order factor analysis including three sub-dimensions of spiritual leadership were used in the analysis, another second factor analysis, including four sub dimensions of PsyCap, was conducted. Model fit indexes of this structure were found to be: $\mathrm{X} 2 / \mathrm{df}=2.234, \mathrm{GFI}=0.901, \mathrm{TLI}=0.957$, $\mathrm{CFI}=0.960, \mathrm{PNFI}=0.851, \mathrm{RMSEA}=0.042$. As a result, it was concluded that fit indexes could be accepted as being in the desired level $(\mathrm{Hu}$ \& Bentler,1999; Lomax \& Schumacker, 2012). Furthermore, unidimensionality was ensured owing to the fact that all factor loadings were above the desired level - above 0.7 - and convergent validity and model fit indexes were at the desired levels (Anderson \& Gerbing, 1988).

Furthermore, in order to test the reliability of factor structures, AVE (Average Variance Extracted) (Fornell \& Larcker, 1981) and SCR (Scale Composite Reliability) values were used (Bagozzi \& Yi, 1988). When the AVE value is above 0.5 and when the $C R$ value is above 0.7 , it is proper to claim that related factors ensure validity and reliability (Bagozzi \& Yi, 1988). AVE and SCR values regarding the factors in 
this study are presented in Tab. 2. According to these values, our factors' validity and reliability are at the desired levels. Moreover, in Tab. 2 discriminant validity is examined by comparing the square root of AVE and vertical-horizontal axis correlation coefficients. Due to the fact that for each factor AV square roots of AVE are higher than correlations at the verticalhorizontal axis, it can be deduced that there is differential validity among factors (Hair et al., 2010).

\section{Results}

In this study, structural equation modelling (SEM) was used to test the hypotheses. As a result of the analysis, it was proven that both the path leading to psychological capital from spiritual leadership $(\beta=0.581, p<0.001)$ and the path from psychological capital to employee performance were statistically significant $(\beta=0.808, p<0.01)$. These findings provide support for $\mathrm{H} 1$ and $\mathrm{H} 2$ as seen in the research model in Fig. 1. And findings of the hypothesis tests are summarized in Tab. 3 .

Furthermore, the mediating effect of organizational identification has been explored by following the processes of Baron and Kenny (1986) and Preacher and Hayes (2008), implemented through a series of structural equation models reported in Tab. 4. As Model 1 suggests, spiritual leadership has a significant effect on firm performance $(\beta=0.565$, $p<0.001$ ) and, according to the findings of Model 2, the paths linking spiritual leadership to psychological capital and psychological capital to employee performance were statistically significant, whereas the relationship between spiritual leadership and employee performance was found to be non-significant $(\beta=0.047$; $p>0.05)$. In order to measure validity of the mediator effect by using the Bootstrap method in a 5,000 sample level, the indirect effects of spiritual leadership on employee performance were explored (Preacher \& Hayes, 2008) and the availability of a meaningful indirect effect $(\beta=0.336 ; p<0.05)$ has been proven to a 95 percent confidence level. According to these results, psychological capital has a perfect mediating effect in the relationship between spiritual leadership and employee performance. Thus, $\mathrm{H} 4$ is supported.

\section{Discussion}

As mentioned before, by nourishing people's inner life, spiritual leadership develops congruent values, attitudes, and behaviors that result in an inner motivation cycle that contributes to a sense of spiritual well-being (Fry

\section{Tab. 3: Structural model and hypothesis testing}

\begin{tabular}{|c|c|c|c|c|c|c|}
\hline & & Model 1 & Model 2 & & & \\
\hline $\begin{array}{l}\text { Spiritual } \\
\text { Leadership }\end{array}$ & $\begin{array}{l}\text { Employee } \\
\text { Performance }\end{array}$ & \multicolumn{2}{|c|}{$0.565(12,485)^{* * *}$} & \multicolumn{3}{|c|}{ Indirect Effect } \\
\hline $\begin{array}{l}\text { Spiritual } \\
\text { Leadership }\end{array}$ & Psy Cap & & $0.581(12,208)^{\star \star *}$ & Estimate & \multicolumn{2}{|c|}{$\begin{array}{l}\text { Confidence } \\
\text { Intervals }\end{array}$} \\
\hline $\begin{array}{l}\text { Psychological } \\
\text { Capital }\end{array}$ & \multicolumn{2}{|c|}{ Employee Performance } & \multicolumn{2}{|l|}{$0.808(13,972)^{\star \star *}$} & Lower & Upper \\
\hline \multirow[t]{5}{*}{$\begin{array}{l}\text { Spiritual } \\
\text { Leadership }\end{array}$} & \multicolumn{2}{|c|}{ Employee Performance } & $0.047(1,276) \mathrm{ns}$ & $0.336^{* * *}$ & 0.324 & 0.452 \\
\hline & \multicolumn{6}{|c|}{$\begin{array}{l}\text { Model Fit; } \mathrm{X} 2 / \mathrm{df}=2.234, \mathrm{GFI}=0.901, \mathrm{TLI}=0.957, \mathrm{CFI}=0.960, \mathrm{PNFI}=0.851 \text {, } \\
\text { RMSEA }=0.042\end{array}$} \\
\hline & \multicolumn{6}{|c|}{ Standardized coefficient are reported with $t$-values in parentheses, } \\
\hline & \multicolumn{6}{|c|}{ a; 5,000 Bootstrap Samples, 95\% Confidence Interval } \\
\hline & \multicolumn{6}{|c|}{${ }^{* * *} p<0.001,{ }^{* *} p<0.01,{ }^{*} p<0.05$, ns $=$ not significant } \\
\hline
\end{tabular}




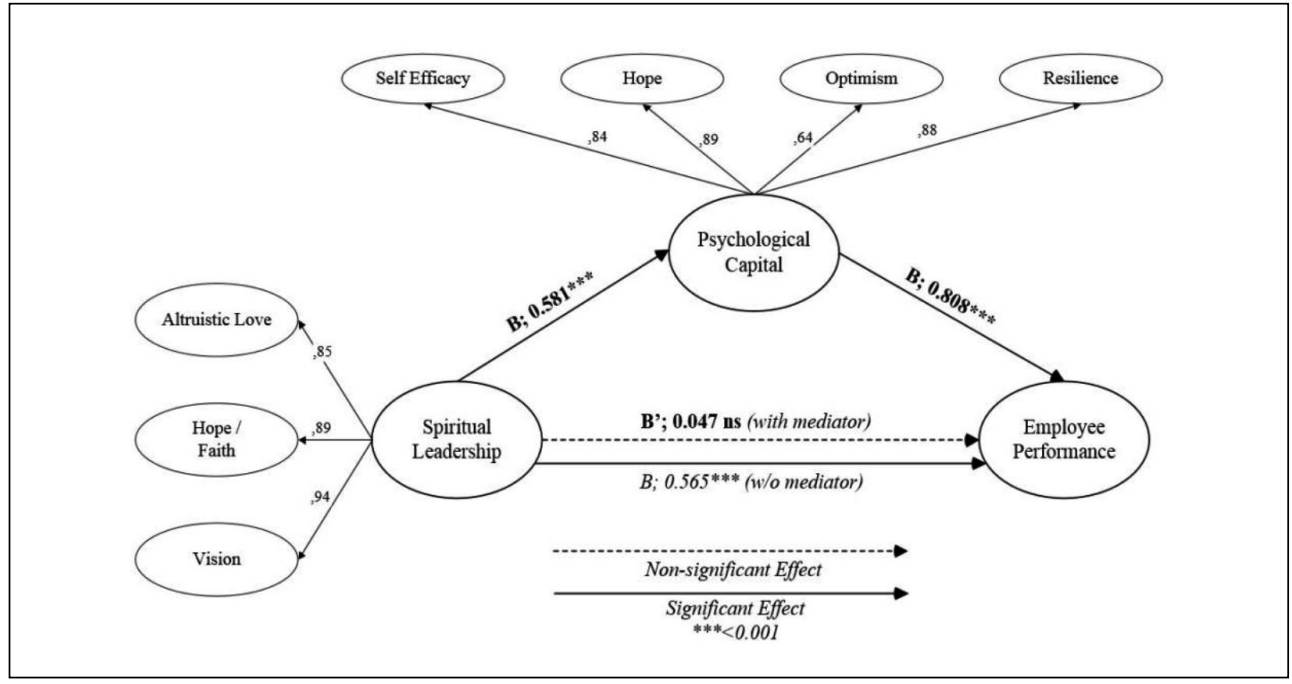

Source: own

\& Cohen, 2009). Organizational spiritualism and satisfaction developed via these concepts create a work environment full of love for one's organization and job which results in higher organizational faithfulness and productivity (Fry, 2003).

In this study, a framework for understanding the effects of spiritual leadership has been developed in the light of its effects on enhancing followers' psychological capacities. Spiritual leadership behaviors' effects on performance (Neck \& Milliman, 1994; Fry, 2003; Duchon \& Plowman, 2005; Fry \& Slocum, 2008; Chen \& Yang, 2012) and the relationship between psychological capital and performance (Luthans, 2002; Stajkovic, 2006; Luthans et al., 2007; Walumbwa et al., 2009; Avey et al., 2010) have been examined many times, but the effects of spiritual leadership on the PsyCap of followers and, also, the effects of spiritual leadership on followers' performance via its effect on their PsyCap have not been studied in the extant literature. Thus, the present study illuminates the relationship between spiritual leadership on PsyCap and employee performance and contributes to the extant leadership and positive organizational behaviour literature by explaining the changes in PsyCap under spiritual leadership.
The results indicate that PsyCap acts as a perfect mediator in the relationship between spiritual leadership and employee performance. Moreover, it has been proven that spiritual leadership has a significant effect on PsyCap of followers and PsyCap also has a positive effect on follower performance. Our results are in parallel with extant literature in explaining the positive relationship between spiritual leadership and performance (Fry, 2003; Fry, 2005; Fry \& Slocum, 2008; Chen \& Yang, 2012; Salehzadeh et al., 2015) and the relationship between PsyCap and performance (Luthans, 2002; Luthans et al., 2005; Avey et al., 2010; Luthans et al., 2007; Luthans et al., 2008; Walumbwa et al., 2009; Gooty et al., 2009). Results show that the followers who work under spiritual leadership experience enhanced PsyCap and this contributes to better levels of success.

\section{Conclusion}

The present study endeavours to make several contributions to the leadership and positive organizational behaviour literature, especially in the context of explaining the relationship between psychological capacities of followers and their performance, and the effects of spiritual leadership on this relationship. In the 
extant literature there is a scarcity in the number of studies regarding the relationship between spiritual leadership and psychological capacity and there is also a scarcity in the number of studies regarding the relationship between psychological capacity and performance. When it comes to a model that takes into consideration all these three factors, this study is the first attempt that has a holistic approach embracing all these dimensions, thus taking an important step in explaining the positive effects of spiritual leadership on strengthening psychological capacities of followers. Moreover, in this study we have taken an important step in explaining employee behaviour by combining the spiritual leadership point of view and positive organizational behaviour mentality.

\section{Research Limitations}

The research was conducted using a great number of samples, but its results should be considered alongside its limitations. First of all, because of the structure of the Turkish business environment, our sample was limited to mostly a few sectors; i.e., finance, banking, and service sectors. Secondly, the study was conducted using a limited geography: Marmara region, especially İstanbul. In Turkey, nearly $90 \%$ of corporate large scale firms are located in İstanbul and the firms conforming to our research criteria - large scale firms with headquarters in İstanbul and having more than 1,000 personnel and 100 branches all over Turkey - are mostly firms from the finance, banking, and FMCG production sectors; thus, we had to apply our survey to this limited number of sectors. Nontheless, a more holistic study in Turkey may result in different answers to our questions due to the cultural differences in different regions of the country or a wider set of criteria could be designated and a wider scope of sectors could be included in further research. Thirdly, we confined our research questions to white-collar workers; different results could be obtained if blue-collar workers were involved. This research could also be replicated in different sectors, with different groups of employees from different parts of Turkey. In addition, the study could be replicated among blue-collar workers, especially in the manufacturing sector or in non-profit organizations in order to see the differences in results compared with the service sector.

\section{Managerial Implications}

In the light of our study, it is expected that managers working especially with white-collar workers could be more successful in directing their organizations towards organizational goals when they touch their followers' souls and minds. Being led by spiritual leadership contributes to a considerable increase in the psychological capacities of followers and this situation results in higher levels of performance. Hence, we propose that managers should give importance to workplace spirituality and serve as a mechanism that supplies the necessary atmosphere for the spiritual growth of their followers.

\section{References}

Anderson, J. C., \& Gerbing, D. W. (1988). Structural equation modeling in practice: A review and recommended two-step approach. Psychological Bulletin, 103(3), 411-423.

Ashmos,D.P., \&Duchon,D.(2000). Spirituality at work: a conceptualization and measure. Journal of Management Inquiry, 9(2), 134-145. https:// dx.doi.org/10.1177/105649260092008.

Avey, J. B., Luthans, F., \& Youssef, C. M. (2010). The additive value of positive psychological capital in predicting work attitudes and behaviors. Journal of Management, 36(2), 430-452. https://dx.doi.org/0.1177/0149206 308329961.

Avey, J. B., Luthans, F., \& Jensen, S. M. (2009). Psychological capital: A positive resource for combating employee stress and turnover. Human Resource Management, 48(5), 677-693. https://doi.org/10.1002/hrm.20294.

Avey, J. B., Reichard, R. J., Luthans, F., \& Mhatre, K. H. (2011). Meta-analysis of the impact of positive psychological capital on employee attitudes, behaviors, and performance. Human Resource Development Quarterly, 22(2), 127-152. https://dx.doi. org/10.1002/hrdq.20070.

Bagozzi, R. P., \& Yi, Y. (1988). On the evaluation of structural equation models. Journal of the Academy of Marketing Science, 16(1), 74-94. https://dx.doi.org/10.1007/ s11747-011-0278-x.

Bandura, A. (1997). Self-efficacy: The Exercise of Control. New York: Freeman.

Bandura, A. (2000). Exercise of human agency through collective efficacy. Current Directions in Psychological Science, 9(3), 75-78. https://doi.org/10.1111/1467-8721.00064. 
Baron, R. M., \& Kenny, D. A. (1986). The moderator-mediator variable distinction in social psychological research: conceptual, strategic, and statistical considerations. Journal of Personality and Social Psychology, 51(6), 1173-1182. https://dx.doi.org/10.1037/00223514.51.6.1173.

Bonelli, R., Dew, R. E., Koenig, H. G., Rosmarin, D. H., \& Vasegh, S. (2012). Religious and spiritual factors in depression: review and integration of the research. Depression Research and Treatment. https://dx.doi. org/10.1155/2012/962860.

Chen, C. Y., \& Yang, C. F. (2012). The impact of spiritual leadership on organizational citizenship behavior: A multi-sample analysis. Journal of Business Ethics, 105(1), 107-114. https://doi.org/10.1007/s10551-011-0953-3.

Chen, C. Y., Yang, C. Y., \& Li, C. I. (2011). Spiritual Leadership, Follower Mediators, and Organizational Outcomes: Evidence from Three Industries Across Two Major Chinese Societies. Journal of Applied Social Psychology, 42(4), 890-938. https://doi.org/10.1111/j.15591816.2011.00834.x.

Duchon, D., \& Plowman, D. A. (2005). Nurturing the spirit at work: impact on unit performance. The Leadership Quarterly, 16(4), 807-833. https://dx.doi.org/10.1007/s10551008-9695-2.

Edwards, J. R., \& Cooper, C. L. (1988). The impacts of positive psychological states on physical health: a review and theoretical framework. Social Science \& Medicine, 27(12), 1447-1459. https://dx.doi.org/10.1016/02779536(88)90212-2.

Fairholm, G. W. (1996). Spiritual leadership: fulfilling whole-self needs at work. Leadership \& Organization Development Journal, 17(5), 11-17. https://dx.doi.org/10.1007/978-0-38784902-7.

Fairholm, G. W. (1998). Leadership as an exercise in virtual reality. Leadership \& Organization Development Journal, 19(4), 187-193. https://doi. org/10.1108/01437739810217160.

Farago, A., \& Gallandar, B. (2002). How to Survive the Recession and the Recovery? Toronto: Insomniac Press.

Fehring, R. J., Miller, J. F., \& Shaw, C. (1997). Spiritual well-being, religiosity, hope, depression, and other mood states in elderly people coping with cancer. Oncology Nursing Forum, 24(4), 663-671.
Fornell, C., \& Larcker, D. F. (1981). Structural equation models with unobservable variables and measurement error: Algebra and statistics. Journal of Marketing Research, 18(3), 382-388. https://dx.doi.org/10.2307/3150980.

Fry, L. W. (2003). Toward a theory of spiritual leadership. The Leadership Quarterly, 14(6), 693-727. https://dx.doi.org/10.1016/j. leaqua.2003.09.001.

Fry, L. W. (2005). Toward a theory of ethical and spiritual well-being, and corporate social responsibility through spiritual leadership. Positive Psychology in Business Ethics and Corporate Responsibility, 47-83. https://dx.doi. org/10.1016/j.leaqua.2005.07.001.

Fry, L. W., \& Slocum, J. W. (2008). Maximizing the triple bottom line through spiritual leadership. Organizational Dynamics, 37(1), 86-96. https://dx.doi.org/10.1016/j. orgdyn.2007.11.004.

Fry, L. W., \& Cohen, M. P. (2009). Spiritual leadership as a paradigm for organizational transformation and recovery from extended work hours cultures. Journal of Business Ethics, 84(Suppl 2), 265-278. https://doi.org/10.1007/ s10551-008-9695-2.

Fry, L. W., Vitucci, S., \& Cedillo, M. (2005). Spiritual leadership and army transformation: Theory, measurement, and establishing a baseline. The Leadership Quarterly, 16(5), 835-862. https://doi.org/10.1016/j. leaqua.2005.07.012.

Fuentes-Fuentes, M. M., Albacete-Sáez, C. A., \& Lloréns-Montes, F. J. (2004). The impact of environmental characteristics on TQM principles and organizational performance. Omega, 32(6), 425-442. https://dx.doi. org/10.1080/00207540500410135.

Giacalone, R. A., \& Jurkiewicz, C. L. (2003). Toward a science of spirituality. In R. A. Giacalone \& C. L. Jurkiewicz (Eds.), Handbook of workplace spirituality and organizational performance (pp. 3-28). New York: M. E. Sharp.

Gooty, J., Gavin, M., Johnson, P. D., Frazier, M. L., \& Snow, D. B. (2009). In the eyes of the beholder transformational leadership, positive psychological capital, and performance. Journal of Leadership \& Organizational Studies, 15(4), 353-367. https:// dx.doi.org/10.1177/1548051809332021.

Hair, J. F., Black, W. C., Babin, B. J., \& Anderson, R. E. (2010). Multivariate Data Analysis. New Jersey: Pearson College Division. 
Hawley, J. (1993). Reawakening the spirit in work: The power of dharmic management. San Francisco: Berrett-Koehler Publishers.

Hu, L. T., \& Bentler, P. M. (1999). Cutoff criteria for fit indexes in covariance structure analysis: Conventional criteria versus new alternatives. Structural Equation Modeling: A Multidisciplinary Journal, 6(1), 1-55. https:// doi.org/10.1080/10705519909540118.

Jurkiewicz, C. L., \& Giacalone, R. A. (2004). A values framework for measuring the impact of workplace spirituality on organizational performance. Journal of Business Ethics, 49(2), 129-142. https://dx.doi.org/10.1007/s10551014-2344-z.

Koenig, H., King, D., \& Carson, V. B. (2012). Handbook of Religion and Health. New York: Oxford University Press. https://dx.doi.org/10.1 080/10508619.2013.845487.

Konz, G. N., \& Ryan, F. X. (1999). Maintaining an organizational spirituality: No easy task. Journal of Organizational Change Management, 12(3), 200-210.

Kouzes, J. M., \& Posner, B. Z. (1993). Transformational leadership. The credibility factor. The Healthcare Forum Journal, 34(4), 16-32.

Lengnick-Hall, C. A., Beck, T. E., \& Lengnick-Hall, M. L. (2011). Developing a capacity for organizational resilience through strategic human resource management. Human Resource Management Review, 21(3), 243-255. https://dx.doi.org/10.1016/j. hrmr.2010.07.001.

Lomax, R. G., \& Schumacker, R. E. (2012). A beginner's guide to structural equation modeling. New York: Routledge Academic.

Lucette, A., Ironson, G., Pargament, K. I., \& Krause, N. (2016). Spirituality and Religiousness are Associated with Fewer Depressive Symptoms in Individuals with Medical Conditions. Psychosomatics, 57(5), 505-513. https://dx.doi.org/10.1016/j. psym.2016.03.005.

Luthans, F. (2002). The need for and meaning of positive organizational behavior. Journal of Organizational Behavior, 23(6), 695-706. https://dx.doi.org/10.1002/job.165.

Luthans, F., Avey, J. B., Clapp-Smith, R., \& Li, W. (2008). More evidence on the value of Chinese workers' psychological capital: A potentially unlimited competitive resource? The International Journal of Human Resource Management, 19(5), 818-827. https://doi. org/10.1080/09585190801991194.
Luthans, F., Avolio, B. J., Avey, J. B., \& Norman, S. M. (2007). Positive psychological capital: Measurement and relationship with performance and satisfaction. Personnel Psychology, 60(3), 541-572. https://doi. org/10.1111/j.1744-6570.2007.00083.x.

Luthans, F., Avolio, B. J., Walumbwa, F. O., \& Li, W. (2005). The psychological capital of Chinese workers: Exploring the relationship with performance. Management and Organization Review, 1(2), 249-271. https://doi.org/10.1111/ j.1740-8784.2005.00011.x.

Luthans, F., Luthans, K. W., \& Luthans, B. C. (2004). Positive psychological capital: beyond human and social capital. Business Horizons, 47(1), 45-50. https://dx.doi.org/10.1016/j. bushor.2003.11.007.

Luthans, F., Norman, S. M., Avolio, B. J., \& Avey, J. B. (2008). The mediating role of psychological capital in the supportive organizational climate-employee performance relationship. Journal of Organizational Behavior, 29(2), 219-238. https://dx.doi.org/10.1002/job.507.

MacArthur, J. (1998). In The Footsteps of Faith: Lessons from The Lives of Great Men and Women of the Bible. Illinois: Crossway Books.

Maddock, R. C., \& Fulton, R. L. (1998). Motivation, Emotions, and Leadership: The Silent Side of Management. London: Greenwood Publishing Group.

Mitroff, I. I., \& Denton, E. A. (1999). A study of spirituality in the workplace. MIT Sloan Management Review, 40(4), 83.

Moxley, R. S. (2000). Leadership and Spirit. San Francisco, CA: Jossey-Bass.

Neck, C. P., \& Milliman, J. F. (1994). Thought self-leadership: Finding spiritual fulfilment in organizational life. Journal of Managerial Psychology, 9(6), 9-16. https://doi. org/10.1108/02683949410070151.

O'Reilly, C. A., \& Pfeffer, J. (2000). Hidden value: how great companies achieve extraordinary results with ordinary people. Harvard Business Press.

Paloutzian, R. F., Emmons, R. A., \& Keortge, S. G. (2003). Spiritual well-being, spiritual intelligence, and healthy workplace policy. In R. A. Giacalone, \& C. L. Jurkiewicz (Eds.), Handbook of Workplace Spirituality and Organizational Performance (pp. 123-136). Armonk, NY: M. E. Sharpe.

Parameshwar, S. (2005). Spiritual leadership through ego-transcendence: exceptional responses to challenging circumstances. 
The Leadership Quarterly, 16(5), 689-722. https://dx.doi.org/10.1016/j.leaqua.2005.07.004.

Pfeffer, J., \& Salancik, G. R. (2003). The External Control of Organizations: A Resource Dependence Perspective. Stanford University Press.

Preacher, K. J., \& Hayes, A. F. (2008). Asymptotic and resampling strategies for assessing and comparing indirect effects in multiple mediator models. Behavior Research Methods, 40(3), 879-891. https://dx.doi. org/10.3758/BRM.40.3.879.

Rahman, S. U., \& Bullock, P. (2005). Soft TQM, hard TQM, and organizational performance relationships: an empirical investigation. Omega, 33(1), 73-83. https://dx.doi.org/10.1016/j.omega.2004.03.008.

Reave, L. (2005). Spiritual values and practices related to leadership effectiveness. The Leadership Quarterly, 16(5), 655-687. https:// dx.doi.org/10.1016/j.leaqua.2005.07.003.

Salehzadeh, R., Khazaei Pool, J., Kia Lashaki, J., Dolati, H., \& Balouei Jamkhaneh, H. (2015). Studying the effect of spiritual leadership on organizational performance: an empirical study in hotel industry. International Journal of Culture, Tourism and Hospitality Research, 9(3), 346-359. https://doi. org/10.1108/IJCTHR-03-2015-0012.

Schroth, R. J., \& Elliot, L. (2002). How Companies Lie: Why Enron is Just the Tip of The Iceberg. New York: Crown Business. https://dx.doi.org/10.1108/ws.2003.07952cae.004.

Simmons, B. L., \& Nelson, D. L. (2001). Eustress at work: the relationship between hope and health in hospital nurses. Health Care Management Review, 26(4), 7-18.

Snyder, C. R., \& Ingram, R. E. (2000). Handbook of psychological change: Psychotherapy processes \& practices for the 21st century. John Wiley \& Sons Inc.

Snyder, C. R., Harris, C., Anderson, J. R., Holleran, S. A., Irving, L. M., Sigmon, S. T., Yoshinobu, L., Gibb, J., Langelle, C., \& Harney, P. (1991). The will and the ways: development and validation of an individual-differences measure of hope. Journal of Personality and Social Psychology, 60(4), 570-585. https://dx.doi.org/10.1037/0022-3514.60.4.570.

Stajkovic, A. D. (2006). Development of a core confidence-higher order construct. Journal of Applied Psychology, 91(6), 1208-1224. https://dx.doi.org/10.1037/0021-9010.91.6.1208.

Stajkovic, A. D., \& Luthans, F. (1998). Selfefficacy and work-related performance: a meta- analysis. Psychological Bulletin, 124(2), 240-261. https://dx.doi.org/10.1037/0033-2909.124.2.240.

Vaughan, M. (1989). The Fabry-Perot interferometer: history, theory, practice and applications. CRC press. Great Malvern.

Walumbwa, F. O., Peterson, S. J., Avolio, B. J., \& Hartnell, C. A. (2010). An investigation of the relationships among leader and follower psychological capital, service climate, and job performance. Personnel Psychology, 63(4), 937-963. https://dx.doi. org/10.1111/j.1744-6570.2010. 01193.x.

Weinberg, F., \& Locander, W. (2014). Advancing workplace spiritual development: a dyadic mentoring approach. The Leadership Quarterly, 25(2), 391-408. https://dx.doi. org/10.1016/j.leaqua.2013.10.009.

Welbourne, T. M., Johnson, D. E., \& Erez, A. (1998). The role-based performance scale: Validity analysis of a theory-based measure. Academy of Management Journal, 41(5), 540-555. https://doi.org/10.5465/256941.

Wrzesniewski, A. (2003). Finding positive meaning in work. In Positive organizational scholarship: Foundations of a new discipline (pp. 296-308).

Youssef, C. M., \& Luthans, F. (2007). Positive organizational behavior in the workplace the impact of hope, optimism, and resilience. Journal of Management, 33(5), 774-800. https:// dx.doi.org/10.1177/0149206307305562.

Zellers, K. L., Perrewe, P. L., Giacalone, R. A., \& Jurkiewicz, C. L. (2003). Handbook of workplace spirituality and organizational performance. New York: ME Sharp.

Zinnbauer, B. J., Pargament, K. I., \& Scott, A. B. (1999). The emerging meanings of religiousness and spirituality: problems and prospects. Journal of Personality, 67(6), 889-919. https://dx.doi.org/10.1111/1467-6494.00077.

Assist. Prof. Elif Baykal, Ph.D. Istanbul Medipol University Medipol Business School Business Administration Turkey enarcikara@medipol.edu.tr

Prof. Cemal Zehir, Ph.D.

Istanbul Yıldız Technical University Managerial and Administrative Sciences Business Management Turkey cemalzehir@gmail.com 


\section{Abstract}

\section{MEDIATING EFFECT OF PSYCHOLOGICAL CAPITAL ONTHE RELATIONSHIP BETWEEN SPIRITUAL LEADERSHIP AND PERFORMANCE}

\section{Elif Baykal, Cemal Zehir}

The challenging and changing business life of the 21st century has resulted in a stressful and negative work atmosphere that negatively charges and demoralizes people. Accordingly, nowadays business life necessitates a more positive approach in handling issues regarding leadership and management. This change in focus has contributed to the fame of spiritual leadership which is a holistic leadership approach that can integrate the minds and souls of people and integrates the four main components of human existence: body, mind, heart, and spirit. Spiritual leadership draws from an inner life nourished by spiritual practices that contribute to the development of values, attitudes, and behaviors that are necessary to intrinsically motivate one's self and result in a sense of spiritual well-being. Spiritual leadership creates the sense that life is purposeful and meaningful; thus, under spiritual leaders, followers feel themselves to be more capable and they show continuous growth and self-realization. In our study, we proposed that spiritual leadership would have a positive effect on the psychological capital of followers, which is a human capacity focusing on the strengths of humans rather than weaknesses; i.e., positivity rather than negativity. Also, we supported the idea that spiritual leadership has a positive effect on performance due to its positive effects on cognitive capabilities of leaders' followers and due to the meaningful and alluring vision that entices followers to perform at their best. We expected that the psychological capacity of followers may have a mediator effect in this relationship. We conducted face-to-face and online surveys with 736 white-collar workers in Turkey and we analyzed our data using SEM. Results of the study confirmed our expectations.

Key Words: Spiritual leadership, psychological capacity, performance.

JEL Classification: M10, M12.

DOI: 10.15240/tul/001/2018-3-008 